\title{
1. The contractual status in context of the rule of law in China: from rational regulation to virtue recognition
}

\section{Qi Tonghui}

\section{INTRODUCTION}

After Niccolò Machiavelli and Thomas Hobbes, "classical political philosophy" changed to "Modern Social Theory", and a significant sign of this transformation was the appearance of "social contract theory". ${ }^{1}$ Especially since the French Revolution, in the political framework of the representative system and democratic consultation, and based on the legitimacy and reality of the model of "struggle for self-preservation", the rule of law shows some progressive "rational" preference: Aristotle's "political man" of Greek city-states changes into Gaius's "legal man" of Roman law, and to Locke's "economic man" who obtained liberty through private property. ${ }^{3}$ The rule of law has hence become a kind of "technology". Accompanied by the Enlightenment, this technical rational preference might be referenced as having "the courage to make use of your own intellect", ${ }^{4}$ as Immanuel Kant put it.

1 Axel Honneth, The Struggle for Recognition, translated by Joel Anderson, Cambridge: The MIT Press, 1995, p. 10.

2 See ibid., pp. 7-10.

3 See J.G.A. Pocock, "The Ideal of Citizenship since Classical Times", in Gershon Shafir, ed., The Citizenship Debates, Minneapolis: The University of Minnesota Press, 1998, pp. 31-41.

4 Immanuel Kant, "An Answer to the Question: What Is Enlightenment", in James Schmidt, ed., What Is Enlightenment? Eighteenth-Century Answers and Twentieth-Century Questions, Berkeley and Los Angeles: University of California Press, 1996, p. 58. 
During the transformation from political man to economic man, after the Enlightenment, something called "universality" was produced by the combination of contract and rationality, and this was used by JeanJacques Rousseau in the sense of political organization. For Rousseau, in a particular regime, the tension between special interests and general interests would be solved by the surrender from the individual will to the general will; it was used by Kant in the sense of ontology, that is to say that the existence of man with moral universality was no longer incidental, for he has a rational necessity; Hegel used it in the sense of epistemology - the objective spirit could be understood as an expression of political organization in the sense of universality. ${ }^{5}$

Contract was used widely during the 16th century, when three great changes occurred in the Western world in the secular rational context: the emergence and development of scientific humanism; religious reform; and a greater focus on national sovereignty. These changes led to the birth of certain ideas, that the country was not created by God, on the contrary, the state should be built in accordance with human ideals and knowledge, and the key issue was to find the most acceptable theoretical resources. While the revival of Roman law since the 13th century and its principles (of course including the contract) has gained widespread recognition in Europe, so the principle of Roman law, especially its contract theory, has become a well-known resource. It has penetrated into the hearts of ordinary people and become the self-evident convention, and naturally gained legitimacy. But the contract theory of Roman law was imagined as a strategy of the constitution of the state; the desire and ability to "find the common in diversity" were still required, becoming fashionable in European society during the 16th and 17th centuries. Similar to the fascination with science at that time, people attempted to find the degree of similarity between any particular objects, and to establish an order for things. Thus, generally, recognition of the principles of contract and "fascination with the common" have become a condition of social contract theory. In addition, the nature of contract also determined the spirit, and the expected gains it represented became the realistic basis of social contract theory: the contract was a rational choice of the promiser after rational judgment. ${ }^{6}$ Thus, the rationality of the rule

5 See Pheng Cheah, "Universal Areas: Asian Studies in a World in Motion", in Naoki Sakai and Yukiko Hanawa, eds, Specters of the West and the Politics of Translation, New York: Cornell University Press, 2002, pp. 55-56.

6 See Su Li, 'From the Contract Theory to Social Contract Theory', 3 Social Sciences in China (1995). 
of law was viewed as related to the contract, and the governance of the rule of law was seen as rational regulation.

However, in addition to the "rationality" of the rule of law, do we not need something else? Furthermore, in the sense of the rule of law, will the "contract" be separated from the "status" forever? In addition to the external "regulation", do we not need the inherent "status"? In fact, for the conclusive judgment "from status to contract", the different views of Chinese scholars have come from diverse angles. ${ }^{7}$

7 Representative views include the following: He Zhaowu argued that in order to rival natural law, Henry James Sumner Maine overdid his judgment, simply ignoring anthropological research (such as MacLennan's works) showing that group marriage existed in ancient times, because this did not follow his concept of paternity. In fact, the most likely scenario was that original gender relations, family and property (ownership) were not regulated by specific rules. If so, then Maine's basic formula would be shaken fundamentally. As a result, all his arguments were more like an inference, that modern people were more individualistic than the ancients. Even so, the formula of "from status to contract" could not be established. See He Zhaowu, "Revaluating Maine's Formula: "From Status to Contract'", 1 Historiography Quarterly (1992); Fu Jingkun believed that with the transition from classical contract law to modern contract law, entering into a contract became a social process, with the parties in this process having a relatively fixed relationship and status, and he therefore argued for the transformation from an absolute relationship to a relative relationship rather than "from status to contract". See Fu Jingkun, Contract Law in 20th Century, Beijing: Law Press, 1997, pp. 62-63; Yu Jiang believed that the value of the traditional contract was credit, rather than freedom or equality. The growing trend of China's contracts was not "from status to contract", but from "status contract to free contract", see Yu Jiang, "It is 'From Status to Contract' or 'Status Contract'”, $5 \mathrm{Du}$ Shu (2002); Zhang Yonghe argued that it seemed unclear whether the concept of "from status to contract" existed in every modern country - it was determined by national law. This kind of status was based on the contract built by the freedom of individual will, thereby the "post-status era" was formed. See Zhang Yonghe, "Blood Status and Contractual Status: The Modern Thinking of Maine's 'From Status to Contract'”, 1 Thinking (2005); Jiang Xianfu argued that the formula of "from status to contract" has been fixed by the characteristic of individualism as popularized in the 19th century - a lack of sustained foresight. See Jiang Xianfu, "The Historical Reproduction of Modern Rechtsstaat: A New Discussion of Maine's 'From Status to Contract'", 2 Law and Social Development (2000); Ding Xiaodong believed that examined by the Confucian grade system of status and its moral discourse, it could be found that a free and equal contract depended on a purely all-powerful public authority or a society of information symmetry, and this was actually impossible. In modern society, status did not disappear but became more complex, an effective contract could not escape the foundation of status, and it is still a rational choice to convey information through status when the governance cost is insufficient. See 
Derived from the problems outlined above, this chapter attempts to cover the following points. First, besides the "rationality" of the rule of law, "the rule of law in China" needs to solve the problem of the "legitimacy of rule of law": what kind of quality should the rule of law possess so it can maintain its existence, and explain its legitimacy? Or, in other words, taking into account the "technology" of the rule of law mentioned above, if it is not seen as a mere technical expedient:

At that point prudence, sovereign over practice, cannot be satisfied with temporary shifts and arrangements, and must extend itself to legislation embodying fundamental, comprehensive choices. Such legislation, in turn, must be guided by an art, ultimately by a theory, that elaborates the model for choice, which is the best, most choiceworthy regime. ${ }^{8}$

Then for the rule of law in the sense of "art", what kind of quality should be possessed? What kind of strategy should be taken? These factors will be called "the virtue of the rule of law" in this chapter.

Second, besides rational contract, "the rule of law in China" also requires "status" - it is the need of the virtue of the rule of law. In contemporary socialist China, the essence of the rule of law is the governance model selected by rationality and stipulated by contract. Such a "rational" context of the rule of law, in fact, contains a diversified "status" based on "virtue". This kind of status will be referred to as "contractual status" in the following analyses.

Third, besides the external regulation, "the rule of law in China" still requires some internal identity. By the "contractual status", such identity provides "distinction", "birthright" and "duty" for the rule of law; it will be called "virtue identity" in this chapter.

I will use Alasdair Chalmers MacIntyre's "Chess Story", Xiaogang village (小岗村) “parceling out land to individual households" in 1978, and the "state-owned enterprises reforms" in 1992 as illustrations, demonstrating the need of "the rule of law in China" to build and maintain a certain "contractual status", not just to apply contract instead of status along the old route of "from status to contract". Contractual status can provide distinction, birthright and duty for the rule of law, concerned with the "absolute - true status" and the "relative - false status", as well as with virtues.

Ding Xiaodong, "Status, Morality, and Free Contract: An Institutional Interpretation of Confucianism", 3 The Jurist (2014).

8 Leo Strauss and Joseph Cropsey, eds, History of Political Philosophy, Chicago and London: The University of Chicago Press, 1987, p. 695. 
Additionally, this chapter attempts to put the argument in some kind of context that can be called "republican liberalism"; that is, it intends to pursue the maximization of individual interests as well as matching those aims to promote common interests. In other words, under this default context, we have, on the one hand, the Republican enthusiasm for citizen participation in public affairs, providing some kind of altruism and openness of information, and, on the other hand, the concern of private affairs supported by liberalism, supplying legitimacy and necessity for rights protection. ${ }^{9}$ The desirability of this default context will be mentioned again at the conclusion of this chapter.

\section{VIRTUE AND STATUS}

Regarding virtue, we need to start by combing through the history of ideas. In the different contexts in the West and China, virtue has complex and multiple meanings. For the West, it can be traced back at least to its Homeric origins, while for China its foundations lie in the Zhou Dynasty.

In traditional China, the concept of virtue started with the transformation of legitimacy from the Shang Dynasty (商) to the Zhou Dynasty (周). In converting from Shang's conception of innate virtue as "leading the people to serve the God" to Zhou's "cultivating virtues to suit the God", obviously, the ideal of acquired virtue adhered to the latter. In the period of Confucius, the ideal of virtue was elucidated by the reciprocal way of "putting oneself in the place of another". In the sense of ontology, focused on the core of "consciousness" (仁) and moral factors such as righteousness, propriety, wisdom, credit, love, honesty and tolerance, eventually dominators were disciplined by Confucian virtues in the dual sense of the life world and politics. If Confucian virtues could exist in the field of legislation, the condition was the co-existence of political Confucianism and Confucian politicization, and the most desirable outcome, through individual training and practice, was that virtue could be universalized. After Confucius, Confucianism's ideal of virtue was continually cultivated by subsequent scholars. Thus, Confucian virtue has been built into the final authority both in theory and action. If consciousness was viewed by Confucius as the core concept, triggering an idea of potential unity between intellect and personality, and obtained the balance between heart and behavior, then, thereafter, based on the "four

9 See Richard Dagger, Civic Virtues: Rights, Citizenship, and Republican Liberalism, Oxford: Oxford University Press, 1997, pp. 113-114. 
hearts", "consciousness" and "righteousness" were integrated by Mencius. From conscientiousness to knowing the essence of life and destiny, the achievement of Mencius was the transformation from the extrinsic to the intrinsic. Rooted in the integration of etiquette and law, from reflecting on the nature of the world to the institution of rites (礼), social intercourse with moral sense was propounded by Xuncius (荀子); the attainment of Xuncius was the transformation from the intrinsic to the extrinsic. Until neo-Confucianism, the accomplishment of which, from studying the nature of things (格物致知) to making rites and music (制礼作乐), was the unification of the intrinsic and the extrinsic. ${ }^{10}$

According to this relationship of inside and outside, in the traditional sense, the governance of virtue contains two meanings: the first is reflective governance, based on efforts self-critique and self-improvement obtained by strengthening the foundations - its perfect state is "inner sageliness" (内圣); the second is practical governance, which embodies ethical standards, intellectual standards and charisma, to act the role of excellent ruler and achieve brilliance in politics - its perfect state is “outer kingliness" (外王).

In the West, the concept of virtue derived from the Greek arete, or excellence, by way of the Latin virtus, which carried with it, from its association with vir (man in the gender-specific sense), the addition of strength and boldness. These connotations certainly persisted in the classical republican theorist's use of civic virtue. ${ }^{11}$ In the era of Aristotle's polis, in Nicomachean Ethics, virtue was described in the following terms: "a human being too will be the state that makes a human being good and makes him perform his characteristic activity well". ${ }^{12}$ In Eudemian Ethics it was defined as the purposeful choice, a habit of action according to the plan of good life. ${ }^{13}$

As the medieval successor of Aristotle, Thomas Aquinas expanded the theory of virtue on two fronts: first, individual virtue would be influenced by $\sin$; second, the ideal of virtue should be understood historically. In some sense, Aristotle's teleological virtue theory was corrected by his successor, as Aquinas argued:

10 See Cheng Zhongying, "A Confucian-Kantian Reflection on the Mutuality and Complementarity of Virtue and Law (I)", 3 Qilu Journal (2009).

11 Richard Dagger, note 9, p. 13.

12 Aristotle, Nicomachean Ethics, translated and edited by Roger Crisp, Cambridge: Cambridge University Press, 2000, p. 29.

13 See Aristotle, The Eudemian Ethics, translated by Anthony Kenny, Oxford: Oxford University Press, 2011, p. xviii. 
Every particular view of the virtues is linked to some particular notion of the narrative structure or structures of human life. In the high medieval scheme a central genre is the tale of a quest or journey. Man is essentially in via. The end which he seeks is something which if gained can redeem all that was wrong with his life up to that point. ${ }^{14}$

It can be clearly seen that the viewpoint which surveys the development of virtue has experienced a process from warrior to gentlemen to clergyman. This is similar to the work of Alasdair MacIntyre, that if virtue was treated as some kind of "quality", then "in the Homeric account the concept of a virtue is secondary to that of a social role, in Aristotle's account it is secondary to that of the good life for man conceived as the telos of human action and in Franklin's much later account it is secondary to that of utility". ${ }^{15}$

Rooted in the tradition of the ideal of virtue above, the relationship of "good" and "practice" in a chess story was used by MacIntyre to illustrate the definition of virtue:

Consider the example of a highly intelligent seven-year-old child whom I wish to teach to play chess, although the child has no particular desire to learn the game. The child does however have a very strong desire for candy and little chance of obtaining it. I therefore tell the child that if the child will play chess with me once a week I will give the child 50 cents worth of candy; moreover I tell the child that I will always play in such a way that it will be difficult, but not impossible, for the child to win and that, if the child wins, the child will receive an extra 50 cents worth of candy. Thus motivated the child plays and plays to win. Notice however that, so long as it is the candy alone which provides the child with a good reason for playing chess, the child has no reason not to cheat and every reason to cheat, provided he or she can do so successfully. But, so we may hope, there will come a time when the child will find in those goods specific to chess, in the achievement of a certain highly particular kind of analytical skill, strategic imagination and competitive intensity, a new set of reasons, reasons now not just for winning on a particular occasion, but for trying to excel in whatever way the game of chess demands. ${ }^{16}$

Obviously, two different goods can be distinguished as this example, the good "externally and contingently attached to chess-playing and to other practices by the accidents of social circumstance - in the case of the imaginary child candy", and the good "internal to the practice of chess

14 Alasdair MacIntyre, After Virtue: A Study in Moral Theory, Notre Dame,

IN: University of Notre Dame Press, 2007, pp. 174-175.

15 Ibid., p. 186 (original emphases).

16 Ibid., p. 188. 
which cannot be had in any way but by playing chess or some other game of that specific kind". ${ }^{17}$ So the definition of virtue argued by MacIntyre was "an acquired human quality the possession and exercise of which tends to enable us to achieve those goods which are internal to practices and the lack of which effectively prevents us from achieving any such goods". ${ }^{18}$

Thus, through the review of the brief history of virtue, it can be found that some common factors are shared by the West and China, making a relatively complete concept of virtue: virtue is a certain quality of some social role, for example a man of noble character, a warrior or a clergyman; virtue has some features based on this role, whether it is introspective or practical; only in the sense of practice can virtue be realized by pursuit - its good belongs to such social roles, and this good can only be achieved through this practice itself. In short, virtue is a "status"; obtaining this status means someone is himself and should act as himself.

\section{FROM STATUS TO CONTRACT?}

In accordance with the intention of Sir Henry Sumner Maine, status is neither overlap of individual rights and obligations, nor a moral, ethical or legal position, but those human conditions associated with legal fiction. Based on these conditions, in the context of the rule of law, if the elements of knowledge and belief, purpose and principles, statement and promises, behavior and integrity can be used properly, and the subject choose their social role correctly, then status is a "capacity" 19 restricted by various factors. But the reality is that this "human condition" and "human capabilities" have been alienated and weakened in the process of moving "from status to contract".

"From status to contract" is the most summarized expression about the progress of the legal system. It alludes to the individual's rights and obligations and their existence as independent from their family - relying

\footnotetext{
17 Ibid., p. 188.

18 Ibid., p. 191.

19 The so-called capacity has different meanings, it is mainly in the capacity regarding "I can", not "I will". See Hannah Arendt, Between Past and Future: Six Exercises in Political Thought, New York: The Viking Press, 1961, pp. 158159. Also, the so-called capacity may include locution, illocution, and perlocution, as illuminated by Slavoj Žižek. See Slavoj Žižek, Enjoy Your Symptom! Jacques Lacan in Hollywood and Out, New York: Routledge, 1992, p. 96.
} 
on their rationality, each individual person establishes autonomous relationships with others by contract. The biggest difference between contract and status is that individuals can control their own choices in terms of self-governance, which is the flowering of the use of rationality after the Enlightenment. However, contract is a means to an end, while status is a state of being, or an associated condition connecting one with the others; it has some ontological meanings. In other words, if the equitable and free relationship of rights and obligations is established by a contract, and if it is stable (at least within a certain time period), then the establishment of a contract is a kind of "status". With respect to the type of status based on birth, class or title, this kind of status is equal and independent, but not so eternal.

Thus, the "status" Maine talked of can also be described as inequality, dependence, as an unmodifiable contract, or a "status contract". While the "contract", regarded by Maine as a sign of progress, can be described as equality, autonomy, diversity and as a modifiable or "contractual status". In fact, "status" is not so easy to cast off, just as "contract" is not so easy to make work.

From the viewpoint of his theory's origins, Maine belongs to the historical school of law. Historical jurisprudence emphasizes the experience and gradual development of institutions formed by social change, deprecating the practice of forging rules through reason advocated by natural law. After a long-term study of Roman law, starting with the concept of Patria Potestas, ${ }^{20}$ Maine argued that people only gradually escape the survival mode of attachment to family to achieve an individualized existence. Accordingly, the conversion from the Patria Potestas to individual ownership can also be expressed as "from status to contract". However, the conversion from Patria Potestas to individual ownership was a transformation concerning the state of individual rights and obligations, it was a process. And more importantly, the person's status would be changed as part of the conversion, i.e., the transformation of rights and obligations would generate the renewal of status. In this regard, the formation of status could not be accomplished at one stroke, it was the result of historical evolution. What "from status to contract" wants to express was under the conditions of democracy, through making equal and free "contracts" people can select, built or change their "status". This is opposed to the basic proposition of the historical school of law that viewed status as the product of historical evolution, as, according to the characteristics of historical evolution, people were

20 Henry Sumner Maine, Ancient Law, London: John Murray, 1861, p. 135. 
basically unable to choose their social status. Therefore, from its theoretical origins, "from status to contract" may be too simple to face a problem of self-contradiction.

From a practical position, "status" was maintained by the lawmakers before the Enlightenment, but what they defended was in fact a "status contract", such as the feudal system in Western Europe, which used "contract" to establish and maintain various dependent "statuses". As Maine stated, "Feudalism, I have repeatedly asserted, was a compound of archaic barbarian usage with Roman law";21 the contractual factors of Roman law had been embedded early.

After the Enlightenment, in some sense "contract" was protected by lawmakers, but no longer concerned the "status" established by contract, even deliberately weakening status. However, the perfect running of a contract could not be guaranteed by this reduction. As Liang Zhiping (梁治平) pointed out, what counts was that the other factors, such as relatives, friends, classmates, etc., could be arranged in place by contract. In a period of social stability or relative stability, social order was maintained more by status, such as the status of "comrade", which could reliably control order in the planned economy era - in a certain period "comrade" was an ultra-institutionalized status, and more favorable for transaction security and rights protection than a contractual relationship. ${ }^{22}$ Therefore in the sense of governance, stating that status was replaced by contract might be to overestimate contract.

To a large extent, "from status to contract" will dispel non-democratic relations between political actors, and to some extent will dispel private interests transactions in the name of "loyalty", but status cannot be changed at once like the property in a contract. In fact, status cannot be replaced by contract, but must be maintained in a changing and pluralistic situation through many contracts. Based on the reality of stable preferences and risk-neutrality, any contract will still show people's "status". If "status" can be seen as the social role of a sense of virtue, this social role was distributed (including mandatory assignment) to the individual by others (including other people, organizations, family, country, etc.) before the Enlightenment. Under the guidance of freedom in a modern democratic society, the social role is distributed to the individual by him or herself in the manner of making a contract. In the sense of virtue, social role means that if the ideal of "from status to contract"

\footnotetext{
21 Ibid., p. 364.

22 See Liang Zhiping, "From Status to Contract: The Revolution of Social Relations", 6 Du Shu (1986).
} 
reveals a process, and the process is only half achieved, can the stability and predictability of the contract be maintained only from "contract" to "institution"? Moreover, the "status" must be given sufficient consideration within the settings of the institution. If the status is never considered by the institution, or has been changed or abolished before the establishment of the institution, anyone trying to regulate society only by contract will instead achieve disorder caused by status confusion. The profound and lasting results are bound to disregard the virtues of status, ignoring existing social roles, and some people will make gains which are not in keeping with their social role.

\section{CONTRACTUAL STATUS: CASES AND EFFECTS}

Actually, status does not disappear under the rational background of the rule of law, it is transformed into "contractual status". Before identifying "contractual status", the elements closely related to this kind of status will be classified into various combinations, these different combinations form the institutional basis of contractual status. In terms of the rule of law, these elements can be divided into three kinds of status - relating to the person, to ownership of property, and to the institutions between connecting persons and property. The relationships of these three elements can be combined into four forms as follows.

Form I establishes an institution, the first step being to determine the status of person, based on the confirmation of status to define the ownership of property. For example, the Land Law of the Chinese Soviet Republic (1931) stipulates "fertile farmland should be allocated to poor peasants, barren should be allocated to rich peasants, and landlords get nothing".

Form II establishes an institution, the first step being to determine rights of property, based on the confirmation of rights of property to define the status. As in the state-owned enterprise (SOE) reforms started in 1992, the ownership of property is defined first and then the workers and laid-off workers are distinguished.

In Form III the ownership of property is determined by noninstitutional actions, based on the ownership of property to determine the status of a person, and finally establishing an institution to regulate those actions. For example, in 1978, "parceling out land to individual households" was used by Xiaogang Village (小岗村) to determine the responsibility of landownership. The 21 farmers who signed the land contract achieved a different status from other villagers - they became the forerunners in this unprecedented pilot program. 
In Form IV the status of person is determined by non-institutional actions, based on the status of a person who determines the ownership of property, and finally establishes an institution to regulate those actions. For example in the Japanese underworld organization of "YamaguchiGumi", its members have a special status on joining and the distribution of interests will be based on this status, and by the institutions of "registration" and "designated Boryokudan" (暴力团) ${ }^{23}$ it can be regulated by Japanese authorities.

In terms of the four forms outlined above, Form I occurred in the process of revolution and Form IV is anchored in a unique Japanese tradition and the specific social reality of the country after the Second World War, so these two forms may be left to one side, while Forms II and III will be the target of serious analysis. Xiaogang village's "parceling out of land to individual households" (包产到户) in 1978, and the SOE reforms in 1992, will be used as examples in the following text.

After the 14th CPC National Congress in 1992, economic reform in China was launched with the reform of SOEs. The steps were as follows: the Third Plenary Session of the 14th Central Committee of the CPC in 1993 proposed focusing on institutional innovation and the establishment of a modern corporate system; during 1994-1995 a policy was endorsed to "retain the large, release the small" (抓大放小); in 1999 this developed into the policy of "both advance and retreat" (有进有退) and "doing certain things and refraining from doing other things" (有所为有所不为). On the consensus of “neither necessary nor possible" to revitalize every state-owned enterprise, some state-owned enterprises were subject to bankruptcy, merger, purchase and reorganization, with a part of the workforce of those enterprises being laid off. ${ }^{24}$ Because SOEs occupy a dominant position in the national economy, and with the development from "reform of SOEs" to "institutional restructuring of SOEs" (IR-SOE 国企改制), so the reform of SOEs can be considered as close to a redistribution of resources. By entering into the various

23 See Wang Junyan, "Why the Japanese Underworld Can Sustain its Legal Existence While Society Can Keep Relative Stability", 2 Zhong Ri Guan Xi Shi Yan Jiu (2013); Yao Tianchong and Zhang Junmei, "The Analyses to the Legality of Japanese Underworld", 2 Japan Studies (2011); Zhou Xinjie, "On the Problem of Japanese Underworld”, 1 Journal of Foreign Studies (1998).

24 See Zhang Chunlin, "The Reforms of State-Owned Enterprises and Social Justice", in Liang Zhiping, ed., Social Justice in the Period of Transformation, Beijing: SDX Joint Publishing Company, 2010, p. 358. 
contracts (including management buy-outs) ${ }^{25}$ to produce the owner of an SOE, the IR-SOE was completed by the new owner signing a contract with the employees he wanted to hire. From the relationship between "status" and "contract", by means of a contract some people's status was changed and established. The most significant and important status changes occurred in two kinds: some people changed from the "formal owner" to the "actual owner", and some people from the "formal owner" to the "actual laid-off" or "actual proletarian", ending up with nothing.

Different from Form II where the institution was established beforehand, in Form III, the institution was established after the definition of property rights and status. By making a "blood alliance" and holding a "secret meeting" on November 24, 1978, 21 farmers risked their lives to sign a contract "parceling out land to individual households". ${ }^{26}$ This practice was rapidly institutionalized as the "Household Contract Responsibility System” (家庭承包责任制) and “the unified and decentralized dual regulating system” (统分结合的双层管理体制), ${ }^{27}$ and became widely popular in the country's rural areas. Since then, the 21 farmers never actually became "commune members" in the sense of "new society, new people" 28 as described by Chen Boda (陈伯达), rather their status subsequently changed to "independent management households" (单干户) and so-called "specialized households" (专业户), “wealthy households” (富裕户) and “outstanding farm households” (冒尖户). ${ }^{29}$

IR-SOE produced two very different situations of status, but from the viewpoint of the "institution" Form II and Form III contained a very close "successive" connection.

In the planned economy period, the greatest contribution Xiaogang Village provided was the separation of ownership and management rights, with the status of independent operator created to challenge inefficient agricultural production patterns. These practices generated a

25 See Qi Tonghui, “Handicaps, Expensive Preference, and Distinguishing Mechanism of Recognition: An Analysis Based on Dworkin's Two Kind of Absurdity", 2 Peking University Law Journal (2012).

26 See Chen Guidi and Chun Tao, The Story of Xiaogang Village, Beijing: Sino-Culture Press, 2009, pp. 12-42.

27 See "Reform is the Great Pioneering Work of the People: The Inspiration from 'Parceling Out Land to Individual Households' of Xiaogang”, 23 Qiu Shi (1998).

28 See Chen Boda, "New Society New People", 3 Hong Qi (1958).

29 See Wang Zhenmin and Sang Xueling, "Household Contract Responsibility System has Brought the Great Reforms in Rural Area", 6 Journal of Social Sciences (1983). 
strong guiding significance to the "reform of SOEs" in 1992 and IR-SOE 2004, or, in some essential sense, Xiaogang's "parceling out land to individual households" was the mother of IR-SOE. Since 1992, when managers of SOEs were found to be inefficient and living beyond their income, looking back to the successes of Xiaogang was actually to find the solution in some kind of "institutional memory". So-called "institutional memory" refers to the fact that after a successful reform or attempts have been experienced, the same type of institution will be remembered, and those memories will form the foundations for the new institution. These memories can be traced back to the direct experience of some institution, that is, today's improvements have certain connections with the past behaviors and the previous experiences of institutions. Furthermore, these memories are usually private and non-transferable, and will be revealed unconsciously or inadvertently. ${ }^{30}$ Thus, the "reform of SOE" and IR-SOE can be imagined as reforms of a Xiaogang style in an urban setting, following the principle of "priority in efficiency" to redefine property and status. That the 21 villagers dared to parcel out land to individual households is the result of previous experiences from both sides of "institutional memory": the negative memories were that Feng Yang (凤阳) had been a poor area since the end of the Han Dynasty (220 AD), and in the process of “determining class status" (划成分) during the period of Land Reform (1950s), Xiaogang, the villagers, unable to select any landlord or rich peasant, were frightened by the prospect of landlessness; the positive memories were that when villagers obtained land before the “Agricultural Cooperation” (农业合作社), their lives gradually improved because of this. ${ }^{31}$ So it was reasonable to say that the 21 villagers were encouraged by these "institutional memories" to participate in the action of parceling out land to individual households. These memories could be summarized by the words of Yan Lizhong (严立忠) who was once the captain of the production team, that was "now all crops from the production team are less than the production of my family previously". 32

As a result of the change of contract, three points can be indicated by the change of status: first, contract "changed" rather than "replaced" status; second, the impetus to change status by contract originated from the so-called "institutional memory"; and third, what contract established was a new form of "contractual status". Thus, we can confirm that

30 See Hui Wang, The Gradual Revolution: China's Economic Reform Movement, New Brunswick: Transaction Publishers, 1994, pp. 202-220.

31 See Chen Guidi and Chun Tao, note 26, pp. 13-15.

32 Ibid., p. 19. 
whether through the contract of "parceling out land to individual households" or the various contracts adopted in IR-SOE, the different statuses do not disappear but merely change their "contractual status" from one type to another.

After the clarification of contractual status, there is still a problem that cannot be ignored, which is why the farmers who distributed land could survive the crisis, gradually becoming better off, but the living conditions of laid-off workers (in the comparable period) were getting worse and worse? In this regard, the policy of "giving priority to efficiency, with due consideration to fairness” (效率优先, 兼顾公平) advertised during IR-SOE can be used as the object, it will be analyzed from two aspects of efficiency and fairness.

Xiaogang's "parceling out land to individual households" can also be expressed as an "institutional restructuring of people's communes"; "property owned by all" was transformed to "private property", but fair allocation principles and methods could not be adopted by the 21 reformers; for example, the land allocated to Yan Hongchang (严宏昌) was very scattered and very inconvenient for farming. ${ }^{33}$ But, finally, success was achieved thanks to the sacrifices of Yan Hongchang and Yan Xuechang (严学昌) - two of the 21 farmers distributing land in 1978. ${ }^{34}$ It could be clearly seen that the allocation of property rights was unfair at that time, but for the 21 reformers, not only was the Pareto optimal maintained by this allocation, but, more important, in the sense of status which generates the basis for landowning, a more far-reaching fairness was achieved. In fact, when controlled by the land system of the people's commune, its members only had a "passive status", which farmers were reluctant to accept. The initiative to restore their status through this land reform achieved a more far-reaching fairness. Higher efficiency was, naturally, the result of this fairness, and it became the core element for promoting rural land reform. Therefore, the practices of Xiaogang were "efficiency promoted by fairness", and the "Household Contract Responsibility System" became an institution, for no other reason than the farmers' active definition of status, which was confirmed by the lawmakers.

In the two aspects of property rights and status, IR-SOE was routed in a different way in the case of Xiaogang. The allocation of property rights was not based on fairness (for example, to mobilize the enthusiasm of everyone, and try to make everyone assume their responsibilities, each

\footnotetext{
33 Ibid., pp. 44-45.

34 Ibid., p. 45.
} 
state-owned enterprise should be restructured in accordance with the number of workers), but on efficiency. In other words, the allocation was inclined to maintain its scale and not bear too great a burden, so as to achieve a so-called great leap forward. The definition of status was not defined in the way of self-identity, but with some kind of "passive" approach, and some people's statuses were changed externally through an institution. The situation of some people was relatively good, such as the owners who had previously been managers and the workers who remained in the enterprise, while some people's situations became worse, such as those who had been laid off. There was no chance to maintain Pareto optimality, so a strategy called Kaldor-Hicks efficiency ${ }^{35}$ would be employed as the institutional arrangement for those who were laid off. In the manner of having "clear property rights" and "reducing redundant staff" to realize the goal of "increased efficiency", "giving priority to efficiency" was regarded as the principle behind IR-SOE; the status of those who were laid off became the carrier for these institutional arrangements. The outcome resulted in the following effects. The first effect was seeking compromise within the institutional framework, such as the policy of "early retirement" that usually requires the cooperation of the SOE and workers to prove that the target workers "engage in underground, high-altitude, high temperature, heavy manual labor or other types of work which are a health hazard, leading to disability due to illness or complete incapacity" 36 - those workers could be granted "early retirement" instead of being laid off. ${ }^{37}$ The second effect was confrontation outside the institutional framework, such as the emergence of the "crime of laid-off workers". ${ }^{38}$ These responses were related to status, the reason being that people have a particular role within a narrative context, and so their psychological resources need some continuity, which means that people must be able to react to the strict apportionment of status. ${ }^{39}$

35 See Nicholas Kaldor, "Welfare Propositions of Economics and Interpersonal Comparisons of Utility", 49(195) The Economic Journal (September 1939), pp. 549-552; J.R. Hicks, "The Foundations of Welfare Economics" 49(196) The Economic Journal (December 1939), pp. 696-712.

36 See Information about Further Improving the Basic Livelihood of Workers Laid Off from State-Owned Enterprises and Ensuring Pensions for Retired Workers (General Office of the State Council (1999) No. 10, 2 February 1999).

37 See Wang Jianxin, ed., China Labour Yearbook, Beijing: China Labour Publishing House, 1998, p. 484.

38 See Ma Lijuan and Yang Hong, "The Crime Investigation of Workers Laid Off from State-owned Enterprises", 10 Contemporary Law Review (supplement, 1999).

39 See Alasdair MacIntyre, note 14, p. 217. 
In summary, changing with the establishment or breaking of contracts, the individual's ethics, even the practical human basis of action and the way of obtaining one's interests, were changed by the transformation of status. In terms of the construction of normative order, its impact was to reproduce the overall symptoms produced by the "lack of consciousness of ethics and professional dignity, which is accompanied by a fundamental danger of despair" 40 proposed by Ji Weidong (季卫东). Its outcome was some kind of realization of Weberian judgment: IR-SOE and the practice of laying off workers had become a kind of selection in the light of "giving priority to efficiency, and due consideration to fairness", a kind of choice to educate and create participants with a view to the profits. According to this selection, the status filtered by selection was exactly as same as Weber's criticism of the so-called "pariahcapitalism", the practitioners of which "stood on the side of the politically and speculatively oriented adventurous capitalism; their ethos was, in a word, that of pariah-capitalism". ${ }^{41}$

\section{VIRTUE IDENTITY: THE STRATEGY BASED ON CONTRACTUAL STATUS}

Strategies can be viewed as the solution to a problem which originated from contractual status, and should start from the concept of status, that is, from the human condition and human ability previously mentioned. The chess example cited in MacIntyre can be changed in line with the analyses as follows, that is, in the context of chess, status can be divided into two kinds.

Status I: Encouraged or attracted by the "bonus", A plays chess with others in order to obtain $\$ 1,000$ as a reward per game played and an extra $\$ 1,000$ dollars as a bonus if he wins. But, in fact, $A$ does not love the sport of chess. Moreover, in addition to playing chess as an occupation, he has other earning capacities (such as food delivery worker or broker). The bonus is the sole purpose of his playing chess, whereby he can live a prosperous life. So $A$ has a status, "chess player" or "the guy playing chess". This is a "relative status", because the act of playing chess itself is not the only and direct reason that he acquired this status; what he wanted was nothing more than obtaining the "bonus" through the game

40 Ji Weidong, The Significance of Legal Procedures, Beijing: China Legal Publishing House, 2004, p. 6.

41 Max Weber, The Protestant Ethic and the Spirit of Capitalism, translated by Talcott Parsons, New York: Routledge, 2005, p. 111. 
of chess. A's status is not defined by a "preference for chess", "preference for bonus" reflects his true status.

Status II: $B$ has an exceptional ability in chess; his passion for chess is extreme and playing chess in the only way in which he can earn a living. In order to support himself he earns bonuses in the same way as $A$ by playing with others. It is the love of chess not the hunt for money (even though he has to obtain the bonuses to earn a living) that provides $B$ with the status, "chess players" or "the guy playing chess". This is an "absolute status", because the behavior of playing chess itself is the only and direct reason that he acquired this status. "Preference for chess" is his true status.

When $A$ loses a game or is not allowed to play, but is still given the promised reward, this is not considered in terms of failure or sadness, because the only issue that matters is whether he can obtain the bonus; or, in other words, once the status of chess player had been lost or there is no chance to earn his deserved benefits in accordance with the status of chess player, $A$ does not feel this to be unfair. But for $B$, to lose a game is more sad than not receiving the bonus, just as winning a game is more pleasing than receiving the bonus; as long as he can make a living, he does not care about whether he receives a bonus or not. Investing himself into the study of chess itself is the most important thing in his life, it is far more important than obtaining the bonus. Hidden behind a false status, $A$ has another true status, while $B$ only maintains a true status. Thus we can also say that, in a sense, "relative status" is a "false status" and "absolute status" is a "true status".

For the two status types, the theories of Ronald Dworkin and Charles Taylor can be used to initiate some further analysis. These can be referred to as "Dworkin-style status" and "Taylor-style status" - based on preferences, the former "wants to" become some kind of person; rooted in recognition, the latter "can" become some kind of person.

According to preference, "Dworkin-style status" can be subdivided into status of "voluntary preferences" and status of "involuntary preferences". If someone is just trying to have a preference rooted in his "desire", this preference is a voluntary preference, it originates from the desire for what he wants to be but cannot be. ${ }^{42} A$ 's status is the status of "voluntary preferences", since earning a bonus is regarded as the only aim for the voluntary choice controlled by $A$ 's desire. But for $B$, earning

42 See Joseph Heath, "Resource Egalitarianism and the Politics of Recognition", in Kevin Olson, ed., Adding Insult to Injury: Nancy Fraser Debates Her Critics, London \& New York: Verso, 2008, p. 210. 
bonuses is only the by-product when he plays chess; his preference is playing chess, but he cannot make a living only by playing chess without making money, money has to be involved in his preference. Although $B$ is dependent on bonuses for his life and earning a bonus accompanies his every game, he is never willing to pursue or maintain such a preference. So, in this sense, $B$ 's status is regarded as the status of "involuntary preferences". Meanwhile, as the analysis above shows, $A$ 's "voluntary preferences" status is a "relative - false status", $B$ 's "involuntary preference" is an "absolute - true status".

In accordance with recognition, "Taylor-style status" can be subdivided into a status of "inner recognition" and a status of "external recognition", similar to "honor" in ancient society, that is, "the background that explained what people recognized as important to themselves was to a great extent determined by their place in society, and whatever roles or activities attached to this position". 43 The status of "inner recognition" is similar to "dignity" in modern society, "It greatly increases the importance of this self-contact by introducing the principle of originality: each of our voices has something unique to say. Not only should I not mold my life to the demands of external conformity; I can't even find the model by which to live outside myself". ${ }^{44}$

In accordance with "Taylor-style status", we find that $A$ 's status cannot be determined. He may have "relative - false status", because from an "external recognition" perspective playing chess has been considered to be a very valuable and praiseworthy activity during some periods, or he may receive social recognition through obtaining bonuses and getting rich through playing chess, and this may be why he chose to play chess, so $A$ chose to become a chess player. At the same time, he may have "absolute - true status". According to "inner recognition", A regarded obtaining bonuses from chess as his most worthwhile thing, and does not care about the evaluation of society. If he can gain recognition from like-minded people, then "chess player" is his "absolute - true status". $B$ 's status can be determined only in terms of "inner status", since the reason that $B$ plays chess is his independent and individual love of the game, unless chess was repealed by some authority or he could not keep pace with developments in the game, as long chess exists, he has only "absolute - true status".

43 See Charles Taylor, Multiculturalism: Examining the Politics of Recognition, edited and introduced by Amy Gutmann, Princeton: Princeton University Press, 1994, p. 31.

44 Ibid., p. 30. 
Based on the analysis above, $B$ can always keep his "absolute - true status" in the two types, but $A$ may have two kinds of "Taylor-style status": through "external recognition" he may have a "relative - false status"; through "inner recognition" he may sustain his "absolute - true status". For the governance of the rule of law, the key problem is effectively distinguishing the status of $A$ and $B$ so they can be given different treatments.

If the governance of the rule of law owns its "virtue", then the three aspects of practice, purpose and quality must be considered seriously by distinguishing the rule of law. Such as in the chess example, the "virtue of chess" and the "virtue of chess player" should be distinguished at the beginning.

On the basis of the "virtue of chess", the rule of law will be in line with not only the three factors (practice, purpose and quality) of chess, but also the spirit of chess - to win every game and improve one's competitiveness. A chess player who pursues both his dignity by winning, and the principle of the "virtue of chess" should follow the rule that seeks effective development. In this mode, some excellent players should be employed without having to focus on their purpose for playing (such as wanting to become rich or smarter or more attractive, etc.), just as their status does not need to be considered (whether "absolute - true status" or "relative - false status"), but rather attention is only paid to their performance in the chess game (to find out between $A$ and $B$ who can win the game). If the "virtue" of the governance of the rule of law is like this, then the selected player's rights and obligations will be stipulated by contract (whether they see themselves as players or not). The player will enjoy high bonuses if he can win, but will get nothing if he loses. That is, the contractual status established by the "virtue of chess" can obtain high returns through the principle of "giving priority to efficiency", but must bear the corresponding responsibility. So, this is a "rightful obligation"; the essence of rights to pursue dignity through efficiency is the obligation to win the game.

If the governance of the rule of law is based on the "virtue of the chess player", according to the factors belonging to the "chess player" (such as $B$ in the "Dworkin-style" or "Taylor-style status", whose purpose, practice and quality can be shown to be playing chess only for sake of the game itself - only through playing chess can $B$ sustain his life and find the meaning of his life, whether rich or poor), then its principle should be the "promise that the chess player can play"; the dignity of the chess player should be protected by "playing chess" rather than "winning the game". Effective protection of a chess player like $B$ is the basic rule in this mode, the people who rely on playing chess should be sought out, 
which means that people like $A$ are excluded, while people like $B$, who may be mediocre but rely on playing chess, become candidates. At this point, the purpose (not trying to get rich or smarter or more attractive by playing chess) and the status (which must be "absolute - true status") need to be paid attention to. Based on the "virtue of the chess player", the rights and obligations of the selected players (who see themselves as real players) will be stipulated by contract too: as long as the player engages in chess games, he can earn a basic living independent of his winning or losing. So this is a "mandatory right" - in essence the obligation to protect a player's dignity is the right to play chess.

From the discussion above, there are at least two problems with IR-SOE. First, it seems that the strategy of IR-SOE is similar to something that operates according to the "virtue of chess", that is, the reform was carried out according to the "virtue of enterprise": "give priority to efficiency" is the guideline, profitable restructuring is the goal, and those who would enforce profitability would be selected as the new owners. But it just "seemed" so; its operations were not really based on the "virtue of enterprise", but strong evidence showed that the reason the new owner could have the chance to hold an SOE business was not because he was able to make businesses profitable, but rather because he could make enterprises unprofitable. ${ }^{45}$ So the first problem is ensuring that the contractual status which is rooted in the "rightful obligations" can be established effectively.

Second, the treatment of workers did not follow the "virtue of participator in the enterprise" (similar to the "virtue of the chess player"). Similar to $B$, those who did not have excellent skills (they only work for the sake of the "work in the enterprise" itself, and can only make their living by "working in the enterprise") were not distinguished from the workers (they can be referred to as $B$; they neither have superb skills nor want to work for the "work in the enterprise" itself, and do not depend on "work in the enterprise") who did not have "virtue of participator of enterprise". So the second problem is making sure that the contractual status which is rooted in "mandatory rights" can be established effectively.

The so-called "contractual status" is no more than a status formed through the medium of "contract" and based on "rule", reflecting human conditions, human capacities and all kinds of restrictions built upon "rule". This was the difference between "contractual status" and "precontract status" during the process of "from status to contract" described

45 See Lang Xianping, "Regulating Property Rights Reform with the Principle of the "Three Musts", 10 Journal of Theoretical Reference (2004). 
by Maine - at that time "rule" was decided by "status", but now "status" is controlled by "rule". Meanwhile, the "rule" itself has its own "virtue", a virtuous rule constitutes a rational rule of law. Based on the complex relationships between virtue, status and contract, contractual status supports positive significances for the rule of law in the following areas.

First, the basis of contractual status is "virtue"; in the context of the rule of law it is as a result of the conditions and capabilities that someone "is himself and should act as himself". On the condition that people's living can be sustained by the institutional default, the actions demonstrated by contractual status will have a greater stability and credibility. Compared to the pure market economic significance conveyed by contract, those actions have more reasonable expectations and can be anticipated effectively. What is more important is that the information hidden in the contract will be displayed by contractual status, thus the contractual status can provide a kind of "distinction" for the rule of law.

Second, "contractual status" emphasizes keeping the initiative in one's own hands, which will prompt every individual involved in the process of the rule of law to do some self-examination, while rights and obligations will be controlled more readily in line with the requirements of the rule of law. This is not only to maximize the return of rationality, it also means that the status which established the autonomous is the "normative status", keeping this status will justify the social order itself. Only when the status is felt independently by someone can the individual legitimacy coincide with the legitimacy of social order. Thus, the contractual status provides the rule of law with a "birthright".

Third, contractual status stresses the "consciousness of role", which is based on the awareness of responsibility in the context of the rule of law. If the governance of the rule of law can be viewed as an opera, the actors must act in accordance with the requirements of the script written by the rule of law, to guarantee our expectations of "public servants with power" and "citizens with rights". The former cannot go beyond the status restrictions of social services and civil service, the latter cannot break through the status restrictions of love for one's country and obeying the rules. Thus, the contractual status provides the rule of law with a "duty".

The discussion of "distinction", "birthright" and "duty" above indicates that the governance of the rule of law in China needs to make undergo dual improvements, that is, the external rational regulation should be improved in relation to the inner virtue identity. 


\section{CONCLUSION: FROM RATIONAL REGULATION TO VIRTUE IDENTITY}

China is confronting its most challenging but also most important times since the 1840 s, this is the period that holds a significant position in the great work of national revival. China is facing various challenges: on the one hand the state wants to establish its legal authority through the rule of law, on the other hand civil society want to maintain its self-reliance. China has an urgent need to foster a viable civil society, but this civil society has to rely on the protection of powerful national institutions. In this case, if the governance of the rule of law wants to take on the triple task of the definition of property rights, the identification of status and institution building, it must exercise a variety of intellectual resources at the level of justice and equity - as a strategy virtue identity needs to be taken seriously.

For the construction of the rule of law, from the perspective of " $i s$ himself and should act as himself", the virtue of the rule of law requires two strategies. The first is to establish the system combined with "rightful obligations" and "mandatory rights", based on different types of virtue; the second is to create the distinguishing mechanism of status through "preference" and "recognition".

If the modern Western transition can be seen as the reference point, one of the biggest challenges is the transformation of status. As Weber discussed, what was needed to transform farmers into salaried workers was to reconstruct their "mentality", and then there was the chance to form their "ethics", 46 thus obtaining a satisfactory status both in faith and secular terms. From 1978, and especially after 1992, China has also been suffering from the challenge of a reconstruction process moving from mentalities to ethics. After the measures - the urbanization of the agricultural population - proposed in the 18th CPC National Congress, in the institutional framework of the rule of law the transformation will be carried out with the famers - are they ready?

Here, the desirability of "republican liberalism" mentioned at the beginning of this chapter can be discussed again. So-called "republican liberalism" requires the governance of the rule of law to work on two sides: on the side of liberalism, let "I" know "myself"; on the side of republicanism, let the "others" know "me". These self-recognition and mutual recognition approaches have been the basis for individual freedom in the sense of social existence since Fichte and Hegel.

46 See Max Weber, note 41, pp. 22-25. 
So, the rule of law in China cannot be merely regarded as a rational "knowledge", it must be a virtue "consensus" through the practice of enhancing people's "insights", so that eventually their mentality, ethics and status are reconstructed by mutual recognition from the inside. What this reconstruction requires is a comprehensive ability: an ability to assign rights and obligations with the awareness of rules, an ability to balance freedom and order with the normative system, and an ability to distinguish fairness and efficiency with contractual status. Put simply, what is needed is an ability to convert rational regulation to virtue recognition. 